\title{
Critical appraisal of the efficacy, safety, and patient acceptability of hydroxyprogesterone caproate injection to reduce the risk of preterm birth
}

This article was published in the following Dove Press journal:

Patient Preference and Adherence

10 July 2013

Number of times this article has been viewed

\author{
Alex CVidaeff \\ Michael A Belfort \\ Division of Maternal-Fetal Medicine, \\ Department of Obstetrics and \\ Gynecology, Baylor College of \\ Medicine and Texas Children's \\ Hospital, Houston, TX, USA
}

\begin{abstract}
Prevention of preterm delivery is a major desiderate in contemporary obstetrics and a societal necessity. The means to achieve this goal remain elusive. Progesterone has been used in an attempt to prevent preterm delivery since the 1970s, but the evidence initially accumulated was fraught by mixed results and was based on mostly underpowered studies with variable eligibility criteria, including history of spontaneous abortion as an indication for treatment. More recent randomized controlled clinical trials restimulated the interest in progesterone supplementation, suggesting that progesterone may favorably influence the rate of preterm delivery. Preterm delivery is a complex disorder and consequently it is unlikely that one generalized prevention strategy will be effective in all patients. Further, an additional impediment in accepting progesterone as the "magic bullet" in the prevention of preterm delivery is that its mechanism of action is not fully understood and the optimal formulations, route of administration, and dose have yet to be established. We have concerned ourselves in this review with the most recent status of 17 alpha-hydroxyprogesterone caproate (17OH-PC) supplementation for prevention of preterm delivery. Our intention is to emphasize the efficacy, safety, and patient acceptability of this intervention, based on a comprehensive and unbiased review of the available literature. Currently there are insufficient data to suggest that $17 \mathrm{OH}-\mathrm{PC}$ is superior or inferior to natural progesterone. Based on available evidence, we suggest a differential approach giving preferential consideration to either $17 \mathrm{OH}-\mathrm{PC}$ or other progestins based on obstetric history and cervical surveillance. Progestin therapy for risk factors other than a history of preterm birth and/or a short cervix in the current pregnancy is not currently supported by the published evidence. The experience to date with $17 \mathrm{OH}-\mathrm{PC}$ indicates that there are population subgroups that may be harmed by administration of $17 \mathrm{OH}-\mathrm{PC}$. Therefore, extending the use of $17 \mathrm{OH}-\mathrm{PC}$ to unstudied populations or for indications that are not evidence-based is inadvisable outside of a research protocol.
\end{abstract}

Keywords: preterm delivery, prevention, 17 alpha-hydroxyprogesterone caproate, efficacy, safety, acceptability

\section{Introduction}

Use of progestins has recently re-emerged as a pharmacologic strategy to improve pregnancy outcomes in women at risk for preterm birth. Endogenous steroid hormones have long been known to regulate endocrine pathways during pregnancy. Estrogens have effects that can both help sustain pregnancy and terminate it by initiating labor. Some of the pregnancy-maintaining effects of estrogens result from their ability to promote synthesis of progesterone. ${ }^{1}$ However, progesterone is the steroid hormone mainly responsible for maintaining the pregnancy through a variety of phases, including morphologic changes to the cervix and myometrium, inhibition of uterine contractions,
Correspondence: Alex C Vidaeff

Department of Obstetrics and Gynecology, Baylor College of Medicine, Texas Children's Hospital, 665I Main Street, Suite FI020, Houston, TX 77030, USA

$\mathrm{Tel}+$ I 8328263737

Fax + I 832825935 I

Email vidaeff@bcm.edu 
and downregulation of the immune system both systemically and at the maternal-fetal interface..$^{2,3}$

The use of exogenous progestins has been advocated for prevention of preterm delivery for almost 40 years. A number of trials have been conducted with conflicting results, and the aggregated body of knowledge lacks reliably reproducible and generalizable evidence of benefit. Interpretation of the available data is particularly difficult because different forms and doses of progestins have been used in disparate study populations. The formulations almost exclusively used have been either natural progesterone (administered either orally or vaginally) or the synthetic progestin 17 alphahydroxyprogesterone caproate (17OH-PC) administered intramuscularly. We reviewed the prevention of preterm birth using progestins in $2009^{4}$ and the reader is referred to that publication for a broad overview. The purpose of this review was to update and organize, in an evidence-based format, the information relating exclusively to $17 \mathrm{OH}-\mathrm{PC}$.

We searched MEDLINE for all publications between January 1966 and March 2013 for articles reporting on progestin use in pregnancy. We used the following search terms: "progesterone", "17-alpha hydroxyprogesterone caproate", "pregnancy", and "preterm delivery". Additional limits were not placed. All articles retrieved from this search were reviewed for the outcome of interest. We selected reports that examined progestin use in relation to preterm delivery and any other articles commenting specifically on $17 \mathrm{OH}-\mathrm{PC}$.

\section{Efficacy of hydroxyprogesterone caproate}

Preterm delivery is a complex problem with varied and incompletely elucidated pathogenic pathways. Consequently, it is unlikely that one generalized interventional approach will be effective in all patients. Indeed, administration of supplemental progesterone is far from being a universal panacea in the fight against preterm delivery. A limiting factor of progesterone prophylaxis is that the current indications for this intervention are based on risk factors for preterm delivery (prior preterm delivery and/or short cervix). However, 50\% of women destined to have a preterm delivery will have no identifiable risk factors. ${ }^{5}$ When given in a low-risk study population $(n=168)$ that was not selected on the basis of risk factors for preterm delivery, $17 \mathrm{OH}-\mathrm{PC}$ administered as a weekly $1000 \mathrm{mg}$ intramuscular dose was ineffective in reducing the rate of preterm birth. ${ }^{6}$ Based on limited data, it appears that progesterone supplementation should not be used as a primary prevention strategy in the general low-risk obstetric population; currently it is only recommended for secondary prevention to reduce the impact of previously expressed risk factors.

The single greatest risk factor for preterm delivery is a history of prior unexplained spontaneous preterm birth. ${ }^{7}$ Studies over the last four decades have found that the synthetic progestin $17 \mathrm{OH}-\mathrm{PC}$ is effective at prolonging pregnancy in some women with singleton pregnancies and previous premature delivery. ${ }^{8}$ However, in spite of the prolongation of pregnancy, statistically significant reductions in perinatal mortality and neonatal morbidity have not been consistently demonstrated. While the timing of birth is important in and of itself for the purpose of investigative hypotheses, prolonging the duration of gestation may not always be in the mother's or the baby's best interest. For example, a baby delivered at 35 weeks' gestation may not necessarily fare better than a baby delivered at 33 weeks if spontaneous delivery was delayed as a result of an intervention that maintained the fetus in an unfavorable environment. The assumption that a greater gestational age at birth automatically translates into a lower risk of neonatal complications may be incorrect. Across studies, definitive evidence for tangible benefits such as increased birth weight, decreased neonatal morbidity, or improved childhood outcomes is inconclusive. Thus, it remains unclear whether $17 \mathrm{OH}-\mathrm{PC}$ prophylaxis results in improved overall perinatal clinical outcome, and the same conclusion is true for other forms of progestins (vaginal or oral). ${ }^{9}$

In 2011, the US Food and Drug Administration (FDA) approved the use of $17 \mathrm{OH}-\mathrm{PC}$ injections traded under the name Makena $^{\text {TM }}$ (KV Pharmaceutical, St Louis, MO, USA) for reducing the risk of recurrent preterm birth in women with a singleton pregnancy. $17 \mathrm{OH}-\mathrm{PC}$ is also available on an individual limited basis in a pharmacy compounded form, although the FDA has recently stated that it recommends that practitioners prescribe the FDA-approved drug rather than a compounded drug unless the prescribing practitioner has determined that a compounded product is necessary for the particular patient and would provide a significant difference for the patient as compared with the commercially available FDA-approved drug product. The FDA further emphasized that it is applying its normal enforcement policies for compounded drugs to compounded $17 \mathrm{OH}-\mathrm{PC} .{ }^{10}$ This has resulted in many compounding pharmacies ceasing to supply compounded $17 \mathrm{OH}-\mathrm{PC}$. Makena and compounded $17 \mathrm{OH}-\mathrm{PC}$ contain the same active (17OH-PC) and inactive (castor oil) ingredients, but only Makena contains preservatives (benzyl benzoate and benzyl alcohol). The FDA has previously approved $17 \mathrm{OH}-\mathrm{PC}$ for use in pregnant women and the agent was marketed as Delalutin ${ }^{\mathrm{TM}}$ (Bristol-Myers 
Squibb, New York, NY, USA) from 1956 for the treatment of recurrent and threatened abortions. In 2000, the FDA withdrew the approval at the request of the holder of the New Drug Application because the company was no longer marketing the drug.

According to the available data, $17 \mathrm{OH}-\mathrm{PC}$ prevents approximately one third of recurrent preterm births. While this is encouraging from an individual standpoint, the public health impact is somewhat limited given that only $15 \%$ of preterm deliveries occur in women with a prior preterm birth. ${ }^{11}$ It has been estimated that if all pregnant women with a history of spontaneous preterm delivery could receive prophylactic progesterone supplementation, the overall preterm delivery rate in the US would be reduced by approximately $2 \% .{ }^{11}$ Furthermore, the approximately $30 \%$ reduction estimate is based on the findings of pooled data from some of the largest reported randomized controlled trials of $17 \mathrm{OH}-\mathrm{PC}$, and it is possible that the enriched control population rate (as high as $54.9 \%$ in the trial reported by the Maternal-Fetal Medicine Units Network $^{12}$ ) may have led to an overestimated benefit. If the risk reduction in real life conditions is lower than one third, the overall impact may be less.

In high-risk women with a history of spontaneous preterm delivery, the responsiveness to $17 \mathrm{OH}-\mathrm{PC}$ is variable and may be genetically influenced. It has been suggested that single nucleotide polymorphisms in the progesterone receptor may play a role, causing women with certain genotypes to actually have an increased risk of preterm delivery when given $17 \mathrm{OH}-\mathrm{PC} .{ }^{13}$ Another potentially important factor impacting the response to $17 \mathrm{OH}-\mathrm{PC}$ is gestational age at the previous preterm delivery. Based on a secondary analysis of a randomized clinical trial, the benefit from 17OH-PC supplementation may be limited to those women who experienced a prior spontaneous birth before 34 weeks' gestation. ${ }^{14}$ This might reduce the universal applicability of $17 \mathrm{OH}-\mathrm{PC}$ in women with a prior preterm birth because only one third of preterm deliveries occur before 34 weeks' gestation. ${ }^{15}$

Cervical shortening in the mid-trimester is another significant risk factor for preterm delivery in both low-risk and high-risk populations. ${ }^{16} 17 \mathrm{OH}-\mathrm{PC}$ was not shown to be more effective than placebo in reducing the rate of preterm delivery in a randomized trial of 657 nulliparous women with a short cervix $(<3 \mathrm{~cm})$ at $16-22$ weeks' gestation. ${ }^{17}$ There are no randomized trials evaluating $17 \mathrm{OH}-\mathrm{PC}$ in women with prior preterm delivery and a short cervix. The only applicable data are derived from a secondary analysis of a randomized clinical trial evaluating the impact of cerclage. This analysis did suggest that $17 \mathrm{OH}-\mathrm{PC}$ may be associated with a reduction in previable birth but there was no significant effect on later preterm deliveries. ${ }^{18}$ Vaginal progesterone, on the other hand, has been shown in several randomized trials in asymptomatic women with a short cervix to be associated with as much as a $38 \%-44 \%$ reduction in the risk for preterm delivery and neonatal death. ${ }^{16,19}$ The individual randomized trials of vaginal progesterone in women with a short cervix did not demonstrate a reduction in the rate of recurrent spontaneous preterm delivery, but the number of such patients enrolled in these studies was small (15\%-21\% of total enrollment). ${ }^{16,19}$ A subsequent individual patient data meta-analysis, allowing increased statistical power, concluded that patients with a history of preterm birth and a short cervix in the current pregnancy may benefit from vaginal progesterone. ${ }^{20}$ However, at this time, the evidence available does not support the addition of vaginal progesterone to $17 \mathrm{OH}-\mathrm{PC}$ or the substitution of $17 \mathrm{OH}-\mathrm{PC}$ with vaginal progesterone if a short cervix is identified in a woman with prior preterm birth who is already on $17 \mathrm{OH}-\mathrm{PC}$. After evaluating the data from the largest available study of vaginal progesterone, ${ }^{18}$ the FDA concluded that the study did not meet the statistical significance generally expected to support the approval of a new product. Compared with the overall efficacy in the trial, the efficacy in the US subgroup was relatively limited, indicating the need for additional investigation. ${ }^{21}$ At this time, a short cervix does not constitute an FDA-approved indication for progesterone supplementation in pregnancy.

Currently, there are insufficient data to suggest that $17 \mathrm{OH}-\mathrm{PC}$ is superior or inferior to natural progesterone. However, it is important to note that the chemical and biochemical properties of $17 \mathrm{OH}-\mathrm{PC}$ and natural progesterone differ in some important ways. ${ }^{22} 17 \mathrm{OH}-\mathrm{PC}$ does not inhibit contractions of human myometrial cells in vitro, whereas progesterone does, presumably acting through nongenomic receptors after preliminary metabolization. ${ }^{23}$ The synthetic derivative $17 \mathrm{OH}-\mathrm{PC}$ is resistant to metabolism by traditional steroid-transforming enzymes, and is thus unlikely to replicate all of the actions of natural progesterone. $17 \mathrm{OH}-\mathrm{PC}$ is not a prodrug, and is not cleaved to 17 alphahydroxyprogesterone, ${ }^{24}$ a metabolite of progesterone already endogenously produced by the placenta in large amounts. ${ }^{25}$ The only metabolism observed with $17 \mathrm{OH}-\mathrm{PC}$ is oxidation by cytochrome P450 3A in hepatocytes to monohydroxy, dihydroxy, and trihydroxy derivatives, with unknown resulting activity. ${ }^{26}$ The metabolism of $17-\mathrm{OH}-\mathrm{PC}$ is inhibited significantly, but with large individual variability, by the endogenous steroids, in particular progesterone. ${ }^{27}$ This relative metabolic stability of $17 \mathrm{OH}-\mathrm{PC}$ ensures a long half-life 
(7.8 days) and allows for less frequent dosing in clinical practice compared with natural progesterone.

In spite of the fact that $17 \mathrm{OH}-\mathrm{PC}$ binds to progesterone receptors with lower affinity than progesterone, both of these substances have similar potency in activating progesterone regulated target genes in cells throughout the classic hormone-hormone receptor pathway. ${ }^{28}$ There are several clinical trials underway investigating direct comparisons of $17 \mathrm{OH}-\mathrm{PC}$ and progesterone. The only published results to date are from Saudi Arabia. In a study of 518 pregnant women with a history of preterm delivery and a normal length cervix who were randomized to either $90 \mathrm{mg}$ vaginal progesterone gel daily or $250 \mathrm{mg}$ of intramuscular $17 \mathrm{OH}-\mathrm{PC}$ weekly, vaginal progesterone was associated with a significantly lower percentage of preterm delivery before 34 weeks' gestation $(16.6 \% \text { versus } 25.7 \%)^{29}$

Progestin therapy for risk factors other than a history of preterm birth and/or a short cervix in the current pregnancy is not currently supported by the published evidence. Progestins do not delay delivery in women with multiple gestation, suggesting that a distinct underlying mechanism of early parturition is present in these women, and that this mechanism is unresponsive to progestins. ${ }^{30-32}$ This argument is supported by in vitro data showing that progesterone does not inhibit stretch-induced mitogen-activated protein kinase activation or gene expression in myometrial cells. ${ }^{33}$ Even in selected asymptomatic twin pregnancy populations with a short cervix (representing a combination of risk factors for preterm delivery), prophylactic $17 \mathrm{OH}-\mathrm{PC}$ did not appear to be beneficial either in a secondary analysis of a large randomized trial, ${ }^{34}$ or in an open-label randomized controlled trial. ${ }^{35}$ In the latter investigation, a higher dose of $17 \mathrm{OH}-\mathrm{PC}$ than in previous clinical trials was used (intramuscular $17 \mathrm{OH}-\mathrm{PC}$ $500 \mathrm{mg}$ twice weekly) to address theoretical concerns about the higher volume of drug distribution in twin compared with singleton pregnancies. This was presumably in response to a report that plasma concentration of $17 \mathrm{OH}-\mathrm{PC}$ is $40 \%$ lower in multiple pregnancies than in singleton pregnancies when the same dosage regimen is employed..$^{36}$ Despite this dose adjustment, $17 \mathrm{OH}-\mathrm{PC}$ had no beneficial impact and the rate of preterm delivery before 32 weeks in the treatment group was twice that of the control group. A planned ancillary study to the Maternal-Fetal Medicine Units Network's randomized trial of $17 \mathrm{OH}-\mathrm{PC}$ in twins ${ }^{37}$ also suggested that women with higher plasma concentrations of $17 \mathrm{OH}-\mathrm{PC}$ had earlier gestational age at delivery. ${ }^{36}$ The authors have also found evidence for early systemic inflammation based on maternal plasma C-reactive protein concentration in women receiving $17 \mathrm{OH}-\mathrm{PC} .{ }^{36}$ Similarly concerning, when studied in a randomized placebo-controlled study of 81 triplet pregnancies, 17OH-PC supplementation was associated with an increase in mid trimester pregnancy loss. ${ }^{38}$ The negative results seen in multiple pregnancies are not influenced by chorionicity or mode of conception. The experience to date with $17 \mathrm{OH}-\mathrm{PC}$ indicates that there are population subgroups that may be harmed by administration of $17 \mathrm{OH}-\mathrm{PC}$. Therefore, extending the use of $17 \mathrm{OH}-\mathrm{PC}$ to unstudied populations or for indications that are not evidence-based is inadvisable outside of a research protocol.

Progesterone therapy in patients in established labor, or those manifesting spontaneous rupture of membranes, uterine contractions, or advanced painless cervical dilatation, cannot be expected to be effective. ${ }^{39} \mathrm{In}$ a small randomized, placebocontrolled trial involving 69 women with premature rupture of membranes at 20-30 weeks' gestation, weekly injections of $17 \mathrm{OH}-\mathrm{PC}$ did not prolong gestation. ${ }^{40}$ Several other studies have investigated the use of $17 \mathrm{OH}-\mathrm{PC}$ in women who remained undelivered after an episode of preterm labor. In one such study, 60 women were randomized to treatment with $17 \mathrm{OH}-\mathrm{PC} 341 \mathrm{mg}$ twice weekly (a dose more than double the routinely used regimen) versus observation. A reduced rate of preterm delivery was observed in women who received 17OH-PC (odds ratio $0.15 ; 95 \%$ confidence interval 0.04-0.58). ${ }^{41}$ However, in a larger randomized study using an even higher dose of 17OH-PC (500 mg twice weekly), the treatment had no effect on the incidence of preterm delivery. ${ }^{42}$ Higher doses of $17 \mathrm{OH}-\mathrm{PC}$ were used in these studies based on the assumption that increased drug exposure would be necessary to stop an ongoing pathologic process. Further, in an observational study, administration of $17 \mathrm{OH}-\mathrm{PC}$ was not associated with a decrease in shortening of cervical length over time. ${ }^{43}$ Thus, at this time, the available evidence is insufficient to recommend $17 \mathrm{OH}-\mathrm{PC}$, at any dose, for maintenance tocolysis.

It is not clear whether $17 \mathrm{OH}-\mathrm{PC}$ provides additional benefit to women with a cerclage in place. One randomized, placebo-controlled study of $17 \mathrm{OH}-\mathrm{PC}$ and cerclage in women with at least two preterm deliveries or mid trimester losses has shown benefit. ${ }^{44}$ In this study, there was a significant reduction in the preterm delivery rate from $37.8 \%$ to $16.1 \%$. In a more recent secondary analysis of data from a randomized trial evaluating cerclage, those women with a prior spontaneous preterm birth, a short cervix in the current pregnancy, and a cerclage in place, did not benefit significantly from addition of $17 \mathrm{OH}-\mathrm{PC} .{ }^{18}$ The same conclusion was reached in a retrospective cohort study of singleton gestation with 
a history of preterm delivery and a cerclage in place in the current pregnancy. ${ }^{45}$

Although there is no supporting evidence suggesting an additive effect of cerclage when $17 \mathrm{OH}-\mathrm{PC}$ is already being given for accepted indications, some clinicians would still consider offering this intervention if cervical shortening is noted, particularly if the cervical length falls below $20-15 \mathrm{~mm} .{ }^{46}$ Of note, a randomized trial comparing cerclage versus $17 \mathrm{OH}-\mathrm{PC}$ in pregnant women with a short cervix $(<25 \mathrm{~mm})$ demonstrated that in those women where the cervical length was $<15 \mathrm{~mm}$, cerclage was more effective than $17 \mathrm{OH}-\mathrm{PC}$ at preventing preterm delivery. ${ }^{47}$

\section{Safety of hydroxyprogesterone caproate}

Exogenous $17 \mathrm{OH}-\mathrm{PC}$ crosses the human placenta efficiently ${ }^{48}$ and the drug is detectable in both maternal and fetal blood for at least 44 days after the last injection. Even when 17OH-PC doses are administered as much as a week apart, plasma concentrations of the drug continue to increase with repeat injection. This is because 17OH-PC is slowly released from the castor oil depots and maternal fat. ${ }^{49}$ Plasma concentration of 17OH-PC shows considerable individual variation at the same dosing regimen and obese women tend to have lower plasma concentrations. The maximum concentration reported after administration of $17 \mathrm{OH}-\mathrm{PC}$ was $0.07 \mu \mathrm{M}$ in maternal plasma ${ }^{50}$ and $0.02 \mu \mathrm{M}$ in cord blood..$^{51}$ The therapeutic concentration of $17 \mathrm{OH}-\mathrm{PC}$ has not been determined and the variable dosages used in the different clinical trials were based on speculation and theoretical assumptions rather than pharmacokinetic parameters.

Progesterone metabolites have been reported to play a role in the pathogenesis of intrahepatic cholestasis of pregnancy. A rise in the serum concentration of progesterone metabolites has been associated with impaired biliary excretion and subsequent accumulation of bile acids..$^{52}$ Elevated serum transaminase activity has been reported in pregnant women treated with oral micronized progesterone, ${ }^{53}$ and withdrawal of treatment has frequently led to improvement in transaminase levels. ${ }^{54}$ The synthesis of endogenous progesterone during normal pregnancy is between $250 \mathrm{mg}$ and $500 \mathrm{mg}$ per day ${ }^{54}$ and concern has been expressed that exogenous progesterone supplementation may impose an additional load on the hepatic transport of sulfated metabolites. In the 1980s and 1990s, oral micronized progesterone was widely used in France at doses of 900-1200 mg daily for women at risk for preterm delivery. The practice was stopped when secondary hepatic effects, including cholestasis of pregnancy, were reported at a higher rate in treated women. ${ }^{55}$ In a prospective observational study $(n=50)$, cholestasis of pregnancy occurred in $64 \%$ of women receiving progesterone versus $36 \%$ in untreated women. ${ }^{54}$ In addition, the diagnosis was made earlier in the treatment group (31 weeks) than in the untreated group (34 weeks). Hepatic effects were not monitored in the clinical trials utilizing 17OH-PC. Doses as high as $2000 \mathrm{mg}$ of $17 \mathrm{OH}-\mathrm{PC}$ per week have been used in clinical practice with no reported maternal or fetal adverse effects, ${ }^{56}$ and doses of $1000 \mathrm{mg}$ weekly have not been shown to affect maternal adrenal function or levels of endogenous steroid hormones. ${ }^{57}$

$17 \mathrm{OH}-\mathrm{PC}$ is inactivated by gastric passage when given by mouth. Compared with orally administered progesterone, progestins given by the vaginal or intramuscular route avoid the hepatic first-pass effect and for this reason may be associated with less hepatic dysfunction. Despite this, some French authors recommend monthly monitoring of serum liver transaminases and bilirubin levels even in patients treated with $17 \mathrm{OH}-\mathrm{PC} .{ }^{58}$

Both adult and fetus have a similar capacity to metabolize 17OH-PC. The presence of an active efflux process for $17 \mathrm{OH}-\mathrm{PC}$ in fetal hepatocytes prevents accumulation of $17 \mathrm{OH}-\mathrm{PC}$ or its metabolites in these cells, minimizing the risk of adverse effects. Inhibition of taurocholate transport by $17 \mathrm{OH}-\mathrm{PC}$ has been observed in fetal hepatocytes, but only at concentrations of at least $0.5 \mu \mathrm{M}$. The measured levels of $17 \mathrm{OH}-\mathrm{PC}$ in cord blood (maximum $0.02 \mu \mathrm{M}$ ) ${ }^{51}$ are lower, suggesting that the likelihood of inhibition of bile transport in the fetus is small.

With regard to other possible maternal side effects, retrospective data suggest that $17 \mathrm{OH}-\mathrm{PC}$ exposure might be associated with an increased risk of gestational diabetes. ${ }^{59,60}$ However, in a more recent secondary analysis of a prospective cohort study, the rates of gestational diabetes were similar between women who did and did not receive 17OH-PC. ${ }^{61}$ Isolated case reports in the literature have also referred to the development of transient Parkinsonism ${ }^{62}$ and autoimmune dermatitis, ${ }^{63}$ apparently related to treatment with $17 \mathrm{OH}-\mathrm{PC}$.

In utero exposure to progestins has not been associated with an increased risk of congenital anomalies, with the possible exception of hypospadias ${ }^{64}$ This possible association has been reported for progestins in general, but not for $17 \mathrm{OH}-\mathrm{PC}$ specifically. The risk is limited to exposure to progestins prior to 11 weeks' gestation, and thus is not relevant to administration of $17 \mathrm{OH}-\mathrm{PC}$ for preterm birth prophylaxis. In addition, $17 \mathrm{OH}-\mathrm{PC}$ recommended for use after 16 weeks' 
gestation is unlikely to cause hypospadias because formation of the phallus is completed before 16 weeks. Currently, no data suggest a link between congenital anomalies and $17 \mathrm{OH}-\mathrm{PC}$ exposure in humans or mice. ${ }^{65,66} \mathrm{~A}$ report from 2005 indicated that exposure to $17 \mathrm{OH}-\mathrm{PC}$ during embryogenesis in rats, at doses similar to those prescribed in humans, may affect the reproductive potential of adult male rats. ${ }^{67}$ However, a more recent extended multigenerational and developmental toxicity study in rats did not corroborate the earlier report. ${ }^{68}$ Although extrapolation of rodent data to humans is difficult, a cautious approach would support initiation of 17OH-PC therapy only after completion of the first trimester of pregnancy. A North American cohort study of 24,000 pregnancies, with 649 offspring who were exposed to $17 \mathrm{OH}-\mathrm{PC}$ and followed up to a mean of 11.5 years of age, showed no increase in congenital anomalies. ${ }^{66} \mathrm{~A}$ population-based, case-control study of 318 women treated with parenteral $17 \mathrm{OH}-\mathrm{PC}$ in the first trimester also showed no detectable teratogenic risk. ${ }^{69}$

The available human developmental data are limited to one study showing no impairment in developmental progress at a mean of 4 years of follow-up. ${ }^{70}$ This study obviously does not include pubertal or reproductive development and does not answer other long-term safety questions. More data are needed to assess definitively the safety of the mother and child exposed to $17 \mathrm{OH}-\mathrm{PC}$ during pregnancy.

Concern has been expressed about a potential safety signal reported as a statistically insignificant increase in pregnancy loss, fetal death, and early preterm birth following exposure to $17 \mathrm{OH}-\mathrm{PC}$ in the second trimester. ${ }^{71,72} \mathrm{~A}$ similar signal for embryo-fetal toxicity had been observed in rhesus monkeys at equivalent human doses, ${ }^{73}$ but no published data provide a rationale for this observed difference in miscarriage and stillbirth rates. A protective action of $17 \mathrm{OH}-\mathrm{PC}$ on the same outcomes, ie, miscarriage and stillbirth, has been reported by others, ${ }^{18}$ highlighting the need for further investigation to evaluate the validity of the expressed concerns. Currently there is such a study underway, with proposed enrollment of more than 1,700 subjects, and is expected to provide more definitive data about the safety of $17 \mathrm{OH}-\mathrm{PC}$ (clinicaltrials.gov).

\section{Acceptance of hydroxyprogesterone caproate}

Prophylactic progestin supplementation is generally initiated at 16 weeks' gestation and continued through 36 weeks of gestation. However, according to a retrospective analysis, later initiation of 17OH-PC prophylaxis, between 21 and
26 weeks' gestation, is as effective as initiation between 16 and 20 weeks. ${ }^{74}$ On the other hand, early discontinuation, before 32 weeks, appears to increase the risk of recurrent late preterm delivery. ${ }^{75}$

In randomized trials, reported side effects have been injection site pain (35\%), injection site swelling (17\%), urticaria (12\%), pruritus $(8 \%)$, nausea and vomiting $(6 \%)$, and injection site nodule (4\%). ${ }^{15}$ Clinical trials in the People's Republic of China of Injectable No 1 (250 mg 17OH-PC and $5 \mathrm{mg}$ estradiol valerate), a once-a-month contraceptive, have shown that the side effects are few and acceptability is high, even with long-term use. ${ }^{76}$

\section{Conclusion}

The lack of reproducible and generalizable evidence of benefit on neonatal and childhood outcomes, combined with considerable uncertainty about the mechanism of action of exogenous progestins, contribute to ongoing debate. Critics question the relative biological activity of exogenous progestins given the fact that maternal plasma progesterone concentrations are already high in the absence of any exogenous hormone, and point out that weekly injections of $17 \mathrm{OH}-\mathrm{PC}$ do not significantly alter the underlying maternal levels. ${ }^{77}$ Exogenous prophylactic injections do not impact the concentration of salivary progesterone either. ${ }^{78}$ Salivary progesterone is a reflection of the biologically active free progesterone in serum.

It has been postulated that progesterone may decrease the risk of preterm delivery through suppressive effects on the immune responses in pregnancy ${ }^{79}$ and by antagonizing the proinflammatory actions of estrogen. ${ }^{80}$ This hypothesis has not been supported in an experimental mouse model where natural progesterone proved ineffective in decreasing the incidence of inflammation-induced preterm parturition. ${ }^{81}$ It is possible that progestins may manifest different antiinflammatory properties in humans, but any possible action is not believed to be exerted through anti-inflammatory mechanisms involving downregulation of nuclear factorkappa B. ${ }^{82}$ The exact pathway via which progestins suppress the inflammatory influences leading to parturition remains a key unanswered question. Adding to the mystery is the recent report in a murine model that neither vaginal progesterone nor $17 \mathrm{OH}-\mathrm{PC}$ has any effect on pathways known to be involved in uterine contractility/quiescence or cervical remodeling. ${ }^{83}$

Future scientific efforts should place specific emphasis on establishing the optimal formulation, route of administration, and dosage for prophylactic administration of progestin. 
Other issues still incompletely appreciated pertain to the optimal target population for use of prophylactic progestin, as well as long-term safety. $17 \mathrm{OH}-\mathrm{PC}$ is part of the available armamentarium for outcome modification in pregnant women with a singleton pregnancy and a history of spontaneous preterm delivery. Its use should be limited to evidence-supported indications, without speculative propositions outside of approved trial settings.

\section{Disclosure}

The authors report no conflicts of interest in this work.

\section{References}

1. Babischkin JS, Grimes RW, Pepe GJ, Albrecht ED. Estrogen stimulation of P450 cholesterol side-chain cleavage activity in cultures of human placental syncytiotrophoblasts. Biol Reprod. 1997;56(1):272-278.

2. Vidaeff AC, Ramin SM. Potential biochemical events associated with initiation of labor. Curr Med Chem. 2008;15(6):614-619.

3. Mendelson CR. Minireview: fetal-maternal hormonal signaling in pregnancy and labor. Mol Endocrinol. 2009;23(7):947-954.

4. Vidaeff AC, Ramin SM. Management strategies for the prevention of preterm birth. Part I: update on progesterone supplementation. Curr Opin Obstet Gynecol. 2009;21(6):480-484.

5. Iams JD, Goldenberg RL, Mercer BM, et al. The preterm prediction study: can low-risk women destined for spontaneous preterm birth be identified? Am J Obstet Gynecol. 2001;184(4):652-655.

6. Hauth JC, Gilstrap LC 3rd, Brekken AL, Hauth JM. The effect of 17 alphahydroxyprogesterone caproate on pregnancy outcome in an active-duty military population. Am J Obstet Gynecol. 1983;146(2):187-190.

7. Carr-Hill RA, Hall MH. The repetition of spontaneous preterm labour. Br J Obstet Gynaecol. 1985;92(9):921-928.

8. Dodd JM, Flenady V, Cincotta R, Crowther CA. Prenatal administration of progesterone for preventing preterm birth. Cochrane Database Syst Rev. 2006;1:CD004947.

9. Likis FE, Edwards DR, Andrews JC, et al. Progestogens for preterm birth prevention: a systematic review and meta-analysis. Obstet Gynecol. 2012;120(4):897-907.

10. US Food and Drug Administration. Updated statement on compounded version of hydroxyprogesterone caproate. Available from: http://www. fda.gov/NewsEvents/Newsroom/PressAnnouncements/ucm308546. htm. Accessed June 16, 2013.

11. Petrini JR, Callaghan WM, Klebanoff M, et al. Estimated effect of 17 alpha-hydroxyprogesterone caproate on preterm birth in the United States. Obstet Gynecol. 2005;105(2):267-272.

12. Meis PJ, Klebanoff M, Thom E, et al. Prevention of recurrent preterm delivery by 17 alpha-hydroxyprogesterone caproate. $N$ Engl $J$ Med. 2003;384(13):2379-2385.

13. Manuck TA, Lai Y, Meis PJ, et al. Progesterone receptor polymorphisms and clinical response to $17 \alpha$-hydroxyprogesterone caproate. Am J Obstet Gynecol. 2011;205(2):131. e1-e5.

14. Spong CY, Meis PJ, Thom EA, et al. Progesterone for prevention of recurrent preterm birth: impact of gestational age at previous delivery. Am J Obstet Gynecol. 2005;193(3 Pt 2):1127-1131.

15. How HY, Sibai BM. Progesterone for the prevention of preterm birth: indications, when to initiate, efficacy and safety. Ther Clin Risk Manag. 2009;5(1):55-64.

16. Fonseca EB, Celik E, Parra M, Singh M, Nicolaides KH. Progesterone and the risk of preterm birth among women with a short cervix. $N$ Engl J Med. 2007;357(5):462-469.

17. Grobman WA, Thom EA, Spong CY, et al. 17 alpha-hydroxyprogesterone caproate to prevent prematurity in nulliparas with cervical length less than $30 \mathrm{~mm}$. Am J Obstet Gynecol. 2012;207(5):390. e1-e8.
18. Berghella V, Figueroa D, Szychowski JM, et al. 17-alphahydroxyprogesterone caproate for the prevention of preterm birth in women with prior preterm birth and a short cervical length. Am J Obstet Gynecol. 2010;202(4):351. e1-e6.

19. Hassan SS, Romero R, Vidyadhari D, et al. Vaginal progesterone reduces the rate of preterm birth in women with a sonographic short cervix: a multicenter, randomized, double-blind, placebo-controlled trial. Ultrasound Obstet Gynecol. 2011;38(1):18-31.

20. Romero R, Nicolaides K, Conde-Agudelo A, et al. Vaginal progesterone in women with an asymptomatic sonographic short cervix in the midtrimester decreases preterm delivery and neonatal morbidity: a systematic review and meta-analysis of individual patient data. Am J Obstet Gynecol. 2012;206(2):124. e1-e19.

21. US Food and Drug Administration. Advisory committees. Available from: http://www.fda.gov/AdvisoryCommittees/Calendar/ucm279859. htm. Accessed March 5, 2012

22. Byrns MC. Regulation of progesterone signaling during pregnancy: implications for the use of progestins for the prevention of preterm birth. J Steroid Biochem Mol Biol. February 11, 2013. [Epub ahead of print.]

23. Ruddock NK, Shi SQ, Jain G, et al. Progesterone, but not $17 \alpha$-hydroxyprogesterone caproate, inhibits human myometrial contractions. Am J Obstet Gynecol. 2008;199(4):391. e1-e7.

24. Yan R, Fokina V, Hankins GD, Ahmed MS, Nanovskaya TN. The effect of esterases on $17 \alpha$-hydroxyprogesterone caproate. Am J Obstet Gynecol. 2008;198(2):221. e1-e5.

25. Tulchinsky D, Simmer H. Sources of plasma $17 \alpha$-hydroxyprogesterone in human pregnancy. J Clin Endocrinol Metab. 1972;35(6):799-808.

26. Sharma S, Ellis EC, Dorko K, et al. Metabolism of 17 $\alpha$-hydroxyprogesterone caproate, an agent for preventing preterm birth, by fetal hepatocytes. Drug Metab Dispos. 2010;38(5):723-727.

27. Cuppett CD, Zhao Y, Caritis S, Zhang S, Zhao W, Venkataramanan R. Effect of endogenous steroid hormones on $17 \alpha$-hydroxyprogesterone caproate metabolism. Am J Obstet Gynecol. 2013;208(1):86. e1-e6.

28. Attardi BJ, Zeleznik A, Simhan H, et al. Comparison of progesterone and glucocorticoid receptor binding and stimulation of gene expression by progesterone, $17 \alpha$-hydroxyprogesterone caproate, and related progestins. Am J Obstet Gynecol. 2007;197(6):591. e1-e9.

29. Maher MA, Abdelaziz A, Ellaithy M, Bazeed MF. Prevention of preterm birth: a randomized trial of vaginal compared with intramuscular progesterone. Acta Obstet Gynecol Scand. 2013:92(2):215-222.

30. Dodd JM, Flenady VJ, Cincotta R, Crowther CA. Progesterone for the prevention of preterm birth: a systematic review. Obstet Gynecol. 2008;112(1):127-134.

31. Caritis SN, Rouse DJ, Peaceman AM, et al. Prevention of preterm birth in triplets using 17 alpha-hydroxyprogesterone caproate; a randomized controlled trial. Obstet Gynecol. 2009;113(2 Pt 1):285-292.

32. Combs CA, Garite T, Maurel K, Das A, Porto M. 17-hydroxyprogesterone caproate for twin pregnancy: a double-blind, randomized clinical trial. Am J Obstet Gynecol. 2011;204(3):221. e1-e8.

33. Lei K, Chen L, Cryar BJ, et al. Uterine stretch and progesterone action. J Clin Endocrionol Metab. 2011;96(6):E1013-E1024.

34. Durnwald CP, Momirova V, Rouse DJ, et al. Second trimester cervical length and risk of preterm birth in women with twin gestation treated with 17- $\alpha$ hydroxyprogesterone caproate. J Matern Fetal Neonatal Med. 2010;23(12):1360-1364.

35. Senat MV, Porcher R, Winer N, et al. Prevention of preterm delivery by 17 alpha-hydroxyprogesterone caproate in asymptomatic twin pregnancies with a short cervix: a randomized controlled trial. Am J Obstet Gynecol. 2013;208(3):194. e1-e8.

36. Caritis SN, Simhan HN, Zhao Y, et al. Relationship between 17-hydroxyprogesterone caproate concentrations and gestational age at delivery in twin gestation. Am J Obstet Gynecol. 2012;207(5):396. e1-e8.

37. Rouse DJ, Caritis SN, Peaceman AM, et al. A trial of 17 alphahydroxyprogesterone caproate to prevent prematurity in twins. N Engl J Med. 2007;357(5):454-461. 
38. Combs CA, Garite T, Maurel K, Das A, Porto M. Failure of 17-hydroxyprogesterone to reduce neonatal morbidity or prolong triplet pregnancy: a double-blind, randomized clinical trial. Am J Obstet Gynecol. 2010;203(3):248. e1-e9.

39. Vidaeff AC. Does weekly progesterone prolong gestation in women who have PPROM? OBG Management. 2011;23(5):18-19.

40. Briery CM, Veillon EW, Klauser CK, et al. Women with preterm premature rupture of the membranes do not benefit from weekly progesterone. Am J Obstet Gynecol. 2011;204(1):54. e1-e4.

41. Facchinetti F, Paganelli S, Comitini G, et al. Cervical length changes during preterm cervical ripening: effects of 17-alpha-hydroxyprogesterone caproate. Am J Obstet Gynecol. 2007;196(5):453. e1-e4.

42. Rozenberg P, Chauveaud A, Deruelle P, et al. Prevention of preterm delivery after successful tocolysis in preterm labor by 17 alphahydroxyprogesterone caproate: a randomized controlled trial. $\mathrm{Am} \mathrm{J}$ Obstet Gynecol. 2012;206(3):206. e1-e9.

43. Durnwald CP, Lynch CD, Walker H, Iams JD. The effect of treatment with 17 alpha-hydroxyprogesterone caproate on changes in cervical length over time. Am J Obstet Gynecol. 2009;201(4):410. e1-e5.

44. Yemini M, Borenstein R, Dreazen E, et al. Prevention of premature labor by 17 alpha-hydroxyprogesterone caproate. Am J Obstet Gynecol. 1985;151(5):574-577.

45. Rebarber A, Cleary-Goldman J, Istwan NB, et al. The use of 17 alphahydroxyprogesterone caproate (17P) in women with cervical cerclage. Am J Perinatol. 2008;25(5):271-275.

46. Society for Maternal-Fetal Medicine Publications Committee. Progesterone and preterm birth prevention: translating clinical trials data into clinical practice. Am J Obstet Gynecol. 2012;206(5): 376-386.

47. Keeler SM, Kiefer D, Rochon M, Quinones JN, Novetsky AP, Rust O. A randomized trial of cerclage vs $17 \alpha$-hydroxyprogesterone caproate for treatment of short cervix. J Perinat Med. 2009;37(5):473-479.

48. Hemauer SJ, Yan R, Patrikeena SL, et al. Transplacental transfer and metabolism of 17-alpha-hydroxyprogesterone caproate. Am J Obstet Gynecol. 2008;199(2):169. e1-e5.

49. Caritis SN, Sharma S, Venkataramanan R, et al. Pharmacology and placental transport of 17-hydroxyprogesterone caproate in singleton gestation. Am J Obstet Gynecol. 2012;207(5):398. e1-e8.

50. Caritis SN, Sharma S, Venkataramanan R, et al. Pharmacokinetics of 17-hydroxyprogesterone caproate in multifetal gestation. Am J Obstet Gynecol. 2011;205(1):40. e1-e8.

51. Sharma S, Ellis EC, Gramignoli R, et al. Hepatobiliary disposition of 17-OHPC and taurocholate in fetal human hepatocytes: a comparison with adult human hepatocytes. Drug Metab Dispos. 2013;41(2):296-304.

52. Vallejo M, Briz O, Serrano MA, Monte MJ, Marin JJ. Potential role of trans-inhibition of the bile salt export pump by progesterone metabolites in the etiopathogenesis of intrahepatic cholestasis of pregnancy. J Hepatol. 2006;44(6):1150-1157.

53. Magnin G, de Meeus JB, Sarfati R, Chaouchi O, Paillat A. [Elevated liver enzymes in a tocolytic treatment with micronized natural progesterone]. Cytolyse hépatique lors d'un traitement tocolytique par la progestérone naturelle micronisée. Presse Méd. 1996;25(3):102-105. French.

54. Bacq Y, Sapey T, Bréchot MC, Pierre F, Fignon A, Dubois F. Intrahepatic cholestasis of pregnancy: a French prospective study. Hepatology.1997;26(2):358-364.

55. Benifle JL, Dumont M, Levardon M, et al. [Effects of natural micronized progesterone on the liver in the third trimester of pregnancy]. Effets de la progest érone naturelle micronisée sur le foie au troisième trimestre de la grossesse. Contracept Fertil Sex. 1997;25(2):165-169. French.

56. Sherman AI. Hormonal therapy for control of the incompetent os of pregnancy. Obstet Gynecol. 1966;28(3):198-205.

57. Onsrud M, Paus E, Haug E, Kjørstad K. Intramuscular administration of hydroxyprogesterone caproate in patients with endometrial carcinoma. Pharmacokinetics and effects on adrenal function. Acta Obstet Gynecol Scand. 1985;64(6):519-523.
58. Carbonne B, Rosenblatt J. Prevention of recurrent preterm birth: a comeback of progesterone? J Gynecol Obstet Biol Reprod. 2005;34(Suppl 1):S127-S136.

59. Rebarber A, Istwan NB, Russo-Stieglitz K, et al. Increased incidence of gestational diabetes in women receiving prophylactic 17 alphahydroxyprogesterone caproate for prevention of recurrent preterm delivery. Diabetes Care. 2007;30(9):2277-2280.

60. Waters TP, Schultz BA, Mercer BM, Catalano PM. Effect of $17 \alpha-$ hydroxyprogesterone caproate on glucose intolerance in pregnancy. Obstet Gynecol. 2009;114(1):45-49.

61. Wolfe K, Dearmond C, How H, Henderson ZT, Sibai B. The rates of abnormal glucose challenge tests and gestational diabetes in women receiving $17 \alpha$-hydroxyprogesterone caproate. Am J Perinatol. 2011;28(10):741-746.

62. Demirkiran M, Aslan K, Bicakci S, Bozdemir H, Ozeren A. Transient parkinsonism: induced by progesterone or pregnancy? Mov Disord. 2004;19(11):1382-1384.

63. Bandino JP, Thoppil J, Kennedy JS, Hivnor CM. Iatrogenic autoimmune progesterone hepatitis caused by 17alpha-hydroxyprogesterone caproate for preterm labor prevention. Cutis. 2011;88(5):241-243.

64. Carmichael SL, Shaw GM, Laurent C, Croughan MS, Olney RS, Lammer EJ. Maternal progestin intake and risk of hypospadias. Arch Pediatr Adolesc Med. 2005;159(10):957-962.

65. Seegmiller RE, Nelson GW, Johnson CK. Evaluation of the teratogenic potential of delalutin (17alpha-hydroxyprogesterone caproate) in mice. Teratology.1983;28(2):201-208.

66. Resseguie LJ, Hick JF, Bruen JA, Noller KL, O'Fallon WM, Kurland LT. Congenital malformations among offspring exposed in utero to progestins, Olmsted County, Minnesota, 1936-1974. Fertil Steril. 1985;43(4):514-519.

67. Pushpalatha T, Reddy PR, Reddy PS. Gestational exposure to hydroxyprogesterone caproate suppresses reproductive potential in male rats. Naturwissenschaften. 2005;92(8):385-388.

68. Schardein JL, Birch R, Hesley R, Thorsrud BA. Multigeneration reproductive study of hydroxyprogesterone caproate (HPC) in the rat: laboratory results and clinical significance. Birth Defects Res B Dev Reprod Toxicol. 2012;95(2):160-174.

69. Dudas J, Gidai J, Czeizel AE. Population-based case-control teratogenic study of hydroprogesterone treatment during pregnancy. Congenit Anom. 2006;46(4):194-198.

70. Northen AT, Norman GS, Anderson K, et al. Follow-up of children exposed in utero to $17 \alpha$-hydroxyprogesterone caproate. Obstet Gynecol. 2007;110(4):865-872.

71. Christian MS, Brent RL, Calda P. Embryo-fetal toxicity signals for 17alpha-hydroxyprogesterone caproate in high-risk pregnancies: a review of the nonclinical literature for embryo-fetal toxicity with progestins. J Matern Fetal Neonatal Med. 2007;20(2):89-112.

72. O'Brien JM, Lewis DF. Progestins for the prevention of spontaneous preterm birth: review and implications of recent studies. J Reprod Med. 2009;54(2):73-87.

73. Hendrickx AG, Korte R, Leuschner F, et al. Embryotoxicity of sex steroidal hormones in nonhuman primates: II. Hydroxyprogesterone caproate, estradiol valerate. Teratology. 1987;35(1):129-136.

74. How HY, Barton J, Istwan N, Rhea DJ, Stanziano GJ. Prophylaxis with 17alpha-hydroxyprogesterone caproate for prevention of recurrent preterm delivery: does gestational age at initiation of treatment matter? Am J Obstet Gynecol. 2007;197(3):260. e1-e4.

75. Rebarber A, Ferrara LA, Hanley ML, et al. Increased recurrence of preterm delivery with early cessation of 17-alpha-hydroxyprogesterone caproate. Am J Obstet Gynecol. 2007;196(3):224. e1-e4.

76. D'Arcangues C. Once-a-month estrogen/progestogen injectables. Entre Nous Cph Den. 1991;(19):15.

77. Reijnders FJ, Thomas CM, Doesburg WH, Rolland R, Eskes TK. Endocrine effects of 17alpha-hydroxyprogesterone caproate during early pregnancy: a double-blind clinical trial. Br J Obstet Gynaecol. 1989;95(5):462-468. 
78. Klebanoff MA, Meis PJ, Dombrowski MP, et al. Salivary progesterone and estriol among pregnant women treated with 17- $\alpha$-hydroxyprogesterone caproate or placebo. Am J Obstet Gynecol. 2008;199(5):506. e1-e7.

79. Critchley HO, Jones RL, Lea RG, et al. Role of inflammatory mediators in human endometrium during progesterone withdrawal and early pregnancy. J Clin Endocrinol Metab. 1999;84(1):240-248.

80. Tibbetts TA, Conneely OM, O’Malley BW. Progesterone via its receptor antagonizes the pro-inflammatory activity of estrogen in the mouse uterus. Biol Reprod. 1999;60(5):1158-1165.
81. Elovitz M, Wang Z. Medroxyprogesterone acetate, but not progesterone, protects against inflammation-induced parturition and intrauterine demise. Am J Obstet Gynecol. 2004;190(3):693-701.

82. Vidaeff AC, Ramin SM, Gilstrap LC 3rd, Bishop KD, Alcorn JL. Impact of progesterone on cytokine-stimulated nuclear factor-kappaB signaling in HeLa cells. J Matern Fetal Neonatal Med. 2007;20(1):23-28.

83. Nold C, Maubert M, Anton L, Yellon S, Elovitz MA. Prevention of preterm birth by progestational agents: what are the molecular mechanisms? Am J Obstet Gynecol. 2013:208(3):223. e1-e7.

\section{Publish your work in this journal}

Patient Preference and Adherence is an international, peer-reviewed, open access journal focusing on the growing importance of patient preference and adherence throughout the therapeutic continuum. Patient satisfaction, acceptability, quality of life, compliance, persistence and their role in developing new therapeutic modalities and compounds to optimize clinical outcomes for existing disease states are major areas of interest. This journal has been accepted for indexing on PubMed Central. The manuscript management system is completely online and includes a very quick and fair peer-review system. Visit http://www.dovepress.com/ testimonials.php to read real quotes from published authors.

Submit your manuscript here: http://www.dovepress.com/patient-preference-and-adherence-journal 